\title{
MAKNA EVALUASI PENYELENGGARAAN PROGRAM PELATIHAN PENDAMPING AKREDITASI FASILITAS KESEHATAN TINGKAT PERTAMA
}

\author{
Aisyah Nurfiani \\ Pendidikan Luar Sekolah, FIP, Universitas Negeri Malang \\ J1. Semarang No. 5 Malang \\ aisyah@yahoo.com
}

\begin{abstract}
Meaning of Training Program Implementasi Evaluation of Accreditation Assistants of Health Facilities at First Level. Program evaluation is a systematic method for assessing the effectiveness and efficiency of the project, policy and program implementation. The purposes of this study is to evaluate implementation of training program conducted by UPT Latkesmas Murnajati, Lawang, based on the implementation guidance published by PPSDM Ministry of Health RI 2011. the evaluation is focused on the participant, facilitators, and training process. The research finding shows that training program conducted by UPT Latkesmas Murnajati have been implemented by fairly well.
\end{abstract}

Keywords: training program, accreditation assistans, health facility

\begin{abstract}
Abstrak : Makna Evaluasi Penyelenggaraan Program Pelatihan Pendamping Akreditasi Fasilitas Kesehatan Tingkat Pertama. Evaluasi program merupakan satu metode ilmiah untuk menilai tingkat efektifitas dan efisien suatu proyek, kebijakan dan program. Penelitian evaluasi ini dilakukan dengan tujuan untuk mengetahui tingkat efektivitas pelaksanaan program pelatihan yang diselenggarakan di UPT Latkesmas Murnajati, Lawang, dengan berpedoman pada pedoman penyelenggaraan pelatihan yang dikeluarkan oleh PPSDM Kementerian Kesehatan RI tahun 2011. Aspek yang dinilai meliputi peserta, fasilitator, dan penyelengaraan pelatihan. Hasil penelitian mendapati bahwa program pelatihan yang diselenggaran oleh UPT Murnajati Lawang telah diselenggarakan dengan cukup baik.
\end{abstract}

Kata Kunci: program pelatihan, pendamping akreditasi, fasilitas kesehatan

Pendidikan merupakan cerminan keberhasilan peningkatan sumber daya manusia suatu bangsa dan negara. Sebagai satuan sistem, pendidikan juga berperan dalam pembangunan Nasional yang memiliki tiga subsistem pendidikan, yaitu pendidikan formal, pendidikan nonformal, dan pendidikan informal. Ketiga subsistem pendidikan tersebut saling berkaitan antara satu dengan lain terutama dalam memenuhi kebutuhan belajar sepanjang hayat.

Pada prosesnya masyarakat tidak dapat berkembang keilmuannyajikahanyamengandalkan pendidikan formal, maka dibutuhkan pendidikan nonformal. dan pendidikan informal yang dapat menunjang kebutuhan belajar masyarakat.

Menurut Robinson (dalam Marzuki (2012:174) "satuan sistem pendidikan nonformal antara lain pelatihan atau diklat, lembaga kursus, Lembaga Swadaya Masyarakat (LSM), home schooling, dan lembaga satuan sejenis lainnya. Pelatihan atau diklat merupakan upaya pengajaran atau pemberian pengalaman kepada seseorang untuk mengembangkan tingkah laku (pengetahuan, skill, sikap).

Seiring dengan berkembangnya ilmu penge- 
pendidikan nonformal maka muncul ragam program pelatihan, hal ini dapat dilihat dengan banyaknya lembaga pelatihan atau diklat salah satunya adalah Unit Pelaksana Teknis (UPT) Pelatihan Kesehatan Masyarakat (Latkesmas) Murnajati Lawang. Sebagai lembaga penerima dan pelaksana pelatihan bentuknya berupa pelatihan teknis kesehatan (substansi dan manajemen), pelatihan fungsional, pelatihan pada masyarakat (kader, mahasiswa, santri, dan kelompok potensial), Training Need Assesment (TNA), dan kegiatan Evaluasi Pasca Pelatihan (EPP). Penyelenggaraannya memiliki sistem yang terorganisir dan terlembagakan.

Peran evaluasi dalam pelatihan dapat diselenggarakan secara terus-menerus, berkala, dan dilakukan sewaktu-waktu. Fenomena tersebut merupakan suatu keunikan yang dapat diteliti sebab selain mengetahui pemaknaan evaluasi penyelenggaraan pelatihan, makna evaluasinya juga bisa sebagai acuhan untuk mengukur keberhasilan program pelatihan. Kegiatan evaluasi yang dilakukan oleh UPT Latkesmas Murnajati Lawang pada saat atau sesudah pelatihan.

Pelatihan pendamping akreditasi FKTP ini berbeda dengan pelatihan kesehatan yang pernah dilaksanakan di UPT Latkesmas Murnajati Lawang. Sasaran pelatihan pendamping akreditasi FKTP berasal dari organisasi struktural Dinas Kesehatan Kabupaten atau Kota, serta Dosen atau Praktisi Kesehatan Universitas yang nantinya dapat mendampingi akreditasi puskemas dan klinik kesehatan di masing-masing daerah wilayah Jawa Timur.

Kondisi-kondisi sebagaimana digambarkan tersebut memerlukan kehadiran Pendidikan Luar Sekolah (PLS) yang berperan menghasilkan solusi melalui penelitian yang dapat dijadikan referensi dalam perbaikan evaluasi penyelenggaraan program pelatihan di UPT Latkesmas Murnajati Lawang.

\section{METODE}

Penelitian ini menggunakan pendekatan kualitatif untuk memahami makna evaluai pada program pelatihan pendamping akreditasi FKTP sebagai fenomena sosial, hal ini sejalan dengan pendapat Cresswell (dalam Patilima 2013:3) yang mengatakan "pendekatan kualitatif sebagai sebuah proses penyelidikan untuk memahami masalah sosial atau masalah manusia berdasarkan pada penciptaan gambar holistik yang dibentuk dengan kata-kata, melaporkan pandangan informan secara terperinci, dan disusun dalam sebuah latar ilmiah". Kemudian menggunakan jenis penelitian fenemenologi dengan maksud memfokuskan untuk mendeskripsikan apa yang sama atau umum dari semua partisipan ketika mengalami fenomena evaluasi penyelenggaraan di UPT Latkesmas Murnajati Lawang dimana kesimpulan membentuk pemahaman yang sama melibatkan satu bentuk penggumpulan data secara efisien dengan hanya memasukkan satu atau lebih wawancara dari informan, data hasil observasi serta studi dokumentasi. Data-datanya merupakan pemaknaan evaluasi penyelenggaraan antara lain yaitu, proses evaluasi penyelenggaraan dan unsur-unsur yang di evaluasi pada penyelenggaraan program.

Kehadiran peneliti sangat penting untuk mengumpulkan data di lapangan, serta digunakan untuk mengungkap fakta-fakta di lapangan. Saat menganalisis data peneliti mengedepankan kemampuan sebagai seorang yang memiliki kapasitas berpikir rasional yang mampu menganalisis temuan-temuan menjadi suatu yang bermakna.

Lokasi penelitian berada di UPT Latkesmas Murnajati Lawang Jalan Argotunggal Nomor 1 Kecamatan Lawang Kabupaten Malang. Data dalam penelitian diperoleh dari subjek yang disebut sumber data. Menurut Ulfatin (2013: 149), informasi yang dapat diungkapkan dalam penelitian umumnya dibedakan menjadi tiga jenis, yaitu fakta, pendapat, dan kemampuan. Teknik pengumpulan data yang digunakan yaitu berupa observasi, wawancara, dan studi dokumentasi". Sarosa (2012: 56) menyampaikan bahwa observasi berguna untuk memudahkan mengamati perilaku dan kehidupan para partisipan dengan cara yang tidak merugikan atau mengganggu partisipan. Pada proses pengamatan atau observasi dimulai dari semua hal yang bersifat umum (general) ke arah yang lebih fokus sampai ke sasaran masalah yang terselektif. Dengan demikian, pertanyaan yang perlu diamati selalu dimulai secara bertahap diarahkan kesasaran yang menyeluruh dan bersifat umum.

Melalui wawancara diketahui tentang pikiran atau pendapat seseorang bahkan pandangan terhadap suatu makna dibalik perkataan atau hal-hal 
lain yang tidak diketahui melalui observasi. Pada proses penelitian teknik wawancara digunakan untuk menggali data yang meliputi pemaknaan proses evaluasi penyelenggaraan program penelitian, dan unsur-unsur yang dievaluasi pada program pelatihan. Sebagai garis besar konsep proses wawancara dalam penelitian ini disesuaikan dengan konteks dan fokus pertanyaan penelitian.

Studi dokumentasi merupakan studi dokumen yang sering digunakan sebagai pelengkap teknik wawancara dan observasi. Dokumen ini berupa foto kegiatan observasi dan wawancara dengan informan, foto kegiatan pelaksanaan program, dan terkait dengan evaluasi program pelatihan.

Analisis data yang digunakan oleh peneliti mengacu pada pendapat Miles \& Hubermen (dalam Komariah dan Satori, 2013:218-220) yaitu, terdapat tiga langkah yang digunakan dalam proses analisis data, yaitu: (1) reduksi data (reduction), (2) penyajian data (display data), dan (3) conclusion drawing/verification kesimpulan merupakan bentuk lain dari verifikasi data kesimpulan.

Pertama Reduksi data (Reduction), langkah pertama yaitu laporan-laporan yang berasal dari hasil wawancara, observasi, dan studi dokumentasi peneliti dilapangan sebagai bahan "mentah" disusun berdasarkan data yang diperoleh direduksi, dirangkum, dipilih hal-hal yang pokok, difokuskan pada hal-hal yang penting. Kemudian yang kedua adalah penyajian data (Display data), dapat dilakukan berbagai bentuk seperti tabel, grafik dan sejenisnya.

Ketiga clonclusion atau adrawing/verification adalah penarikan kesimpulan dan verifikasi. Kesimpulan awal yang dikemukakan masih bersifat sementara, dapat berubah apabila tidak ditemukan bukti-bukti yang kuat mendukung pada tahap pengumpulan data berikutnya.

Proses keabsahan data peneliti menggunakan tiga triangulasi yaitu triangulasi sumber, waktu, dan teknik. Triangulasi sumber adalah dengan: (1) membandingkan data hasil wawancara dengan data observasi, dan (2) membandingkan hasil wawancara dengan isi suatu dokumen lainnya.

Triangulasi teknik pada penelitian ini dilakukan dengan menggunakan dua strategi, yaitu (1) pengecekan derajat kepercayaan penemuan hasil penelitian dengan beberapa macam teknik pengumpulan data, dan (2) pengecekan derajat kepercayaan beberapa sumber data dengan metode yang sama.

Triangulasi waktu pada penelitian dilakukan dengan mengecek konsistensi, kebenaran suatu data dengan waktu. Menguji kredibilitas data dengan mengumpulkan data pada waktu yang berbeda.

Tahap-tahap penilitian dibagi menjadi tiga yaitu tahap pra-lapangan peneliti menentukan tempat penelitian, melakukan perijinan,mencari dan mengumpulkan kajian pustaka, serta menyusunan perencanaan umum tentang kegiatan yang akan dilakukan.

Pada tahap lapangan peneliti mengadakan observasi langsung ke UPT Latkesmas Murnajati Lawang, penulis melakukan wawancara dan studi dokumentasi mengenai hal-hal yang sesuai dengan fokus penelitian serta mengumpulkan data-data yang mendukung dalam penelitian. Kemudian melakukan member check, kegiatan ini dilakukan secara berulang dari data hasil wawancara maupun observasi dan studi dokumentasi. Penelitian dilakukan dari bulan Desember 2015-Mei 2016.

\section{HASIL DAN PEMBAHASAN}

\section{Hasil}

Pelayanan pelatihan yang baik dapat dilihat dengan adanya evaluasi yang memiliki peran sangat dominan dalam penyelenggaraan pelatihan. Karena melalui proses evaluasi yang diselenggarakan dapat mengetahui kualitas dan kuantitas pelatihan yang diselenggarakan melalui kader-kader kesehatan masyarakat atau peserta pelatihan. Peserta pelatihan berperan serta dalam proses menilai pelaksanaan pelatihan.

Dengan demikian proses evaluasi penyelenggaraan yang dilaksanakan oleh UPT Latkesmas Murnajati tidak bisa terlepas dari beberapa jenis evaluasi, tujuannya untuk menilai aspek-aspek tertentu secara garis besar yaitu evaluasi pada peserta, evaluasi fasilitator atau nara sumber, serta penyelenggaraan pelatihan dan beberapa aspek penunjang.

Evaluasi yang dilakukan pada setiap pelatihan, khususnya pelatihan pendamping akreditasi FKTP ini terdiri dari evaluasi pada peserta seperti evaluasi pre test, post test, studi kasus dan komprehensif. Pertama ada pre test dan post test hampir selalu 
dilaksanakan pada setiap pelatihan. Khususnya pelatihan pendamping akreditasi FKTP evaluasi pada peserta berbeda dari pelatihan lainnya dengan adanya komprehensif. Komprehensif dilaksanakan bertujuan untuk menilai tingkat pemahaman peserta pelatihan pada keseluruhan materi yang sudah diberikan oleh fasilitator. Kemudian yang kedua adalah evaluasi fasilitator atau nara sumber, dan ketiga adalah evaluasi penyelenggaraan pelatihan.

Berdasarkan prosesnya, panitia penyelenggara mempunyai kewajiban untuk melaporkan kegiatan pelatihan yang telah diselesaikan dalam bentuk laporan. Laporan penyelenggaraan pelatihan tersebut harus dibuat selambat-lambatnya satu minggu setelah pelatihan berakhir. Sesuai dengan pedoman penyelenggaraan pelatihan Badan PPSDM Kementerian Kesehatan RI tahun 2011.

Sasaran evaluasi penyelenggaraan yaitu peserta pelatihan namun yang terlibat dalam evaluasi adalah semua komponen pelaksanaan pelatihan. Namun untuk keberhasilan suatu program pelatihan tidak dapat terlepas dari segi pelaksanaannya, maka evaluasi terhadap suatu program antara lain kualitas masukan, kualitas proses maupun kualitas hasil pelaksanaan program pelatihan. Prosesnya, evaluasi dapat dilakukan oleh lembaga untuk peserta pelatihan serta peserta pelatihan untuk lembaga.

Sistematika evaluasi penyelenggaraan disesuaikan dengan pedoman penyelenggaraan pelatihan untuk mempermudah pengambil keputusan (evaluator) dalam melakukan peloparan pelaksanaan pelatihan. Pada tahun 1990-an unsur-unsur evaluasi penyelenggaraan yang dilaksanakan memilik perbedaan pada setiap pelaksanaannya. Proses pelaporan yang dilaksanakan berfungsi untuk memberikan informasi dengan mudah mengenai pelaksanan pelatihan. Adanya perbedaan tersebut dibuatlah pedoman penyelenggaraan pelatihan oleh Kementerian Kesehatan RI pada tahun 2011 sebagai acuhan atau pedoman untuk penyelenggaraan dan evaluasi.

Evaluasi penyelenggaraan yang dilaksanakan oleh lembaga memiliki manfaat untuk mendapatkan informasi tentang berhasil atau tidaknya suatu bentuk pelayanan pelatihan seperti kesiapan penyelenggaraan, proses pembelajaran yang dilakukan oleh fasilitator atau narasumber, dan penunjang pelatihan lainnya, digunakan untuk perbaikan program pelatihan, pengembangan atau modifikasi program pelatihan.

Terdapat unsur-unsur yang dievaluasi pada penyelenggaraan program pelatihan pendamping akreditasi FKTP di UPT Latkesmas Murnajati Lawang. Pada setiap proses evaluasi unsur-unsur yang ingin diketahui tingkat keberhasilannya juga berbeda. Pada evaluasi penyelenggaraan terdapat sebelas unsur-unsur yang ingin diketahui nilainya atau keberhasilannya.

Unsur-unsur evaluasi penyelenggaraan di UPT Latkesmas Murnajati Lawang Sebelas unsur yang di evaluasi pada penyelenggaraan pelatihan yaitu: (1) pelayanan belajar dalam pelatihan; (2) penggunaan metode pembelajaran oleh fasilitator/ narasumber; (3) tingkat semangat belajar (motivasi) mengikuti program pelatihan; (4) tingkat kepuasan peserta pelatihan terhadap penyelenggaraan proses belajar; (5) kenyamanan ruang belajar; (6) penyediaan alat bantu pelatihan; (7) penyediaan pelayanan bahan belajar; (8) kebersihan kamar kecil; (9) pelayanan sekretariat; (10) pelayanan akomodasi; (11) pelayanan konsumsi.

Terdapat fungsi dari masing-masing unsur evaluasi penyelenggaraan unsur-unsurnya tersebut memiliki fungsinya masing-masing yaitu: (1) pelayanan belajar dalam pelatihan. Berfungsi menilai proses pembelajaran untuk panitia pelaksana; (2) penggunaan metode pembelajaran oleh fasilitator/narasumber. Berfungsi menilai proses pembelajaran atau gaya mengajar; (3) tingkat semangat belajar (motivasi) mengikuti program pelatihan. Berfungsi menilai pemberian motivasi oleh fasilitator; (4) tingkat kepuasan peserta pelatihan terhadap penyelenggaraan proses belajar. Berfungsi untuk menilai penyelenggaraan belajar; (5) kenyamanan ruang belajar. Berfungsi menilai sarana pelatihan; (6) penyediaan alat bantu pelatihan. Berfungsi menilai prasarana pelatihan; (7) penyediaan pelayanan bahan belajar. Berfungsi menilai kesediaan bahan belajar; (8) kebersihan kamar kecil. Berfungsi menilai sarana pelatihan; (9) pelayanan sekretariat. Berfungsi menilai administrasi pelatihan; (10) pelayanan akomodasi. Berfungsi untuk menilai kesiapan pelaksana pelatihan pada akomodasi peserta pelatihan yang melakukan Praktik Kerja Lapangan (PKL) ke tempat diluar lembaga pelatihan; (11) pelayanan konsumsi. Berfungsi untuk menilai ketersediaan 
konsumsi meliputi coffe break atau konsumsi yang lainnya.

Media evaluasi penyelenggaraan Media yang digunakan pada evaluasi penyelenggaraan berupa media cetak menggunakan kuisioner penilaian untuk evaluasi penyelenggaraan dan fasilitator, serta studi kasus atau soal untuk evaluasi peserta. Media kuisioner dipilih sebagai alat untuk mengetahui keberhasilan pelaksanaan pelatihan dikarenakan merupakan satu-satunya media yang mudah untuk dianalisis oleh evaluator lembaga. Kuisioner digunakan untuk membantu memberikan kemudahan peserta pelatihan dalam memberikan penilaian terhadap pelaksanaan pelatihan yang sedang berlangsung. Penggunaan kuisioner penilaian ini peserta pelatihan dapat diketahui mengenai keadaan atau data diri, pengalaman, pengetahuan sikap, pendapatnya, dan lain-lain.

Oleh sebab itu evaluasi penyelenggaraan difokuskan kepada seluruh kegiatan selama pelatihan mulai dari pembukaan, praktik kerja lapangan (PKL), penutupan serta evaluasi penyelenggaraan pelatihan.

\section{Pembahasan}

Pelayanan pelatihan yang baik dapat dilihat dengan adanya evaluasi yang memiliki peran sangat dominan dalam penyelenggaraan pelatihan. Karena melalui proses evaluasi yang diselenggarakan dapat mengetahui kualitas dan kuantitas pelatihan yang diselenggarakan melalui kader-kader kesehatan masyarakat atau peserta pelatihan. Peserta pelatihan berperan serta dalam proses menilai pelaksanaan pelatihan. Hal tersebut didukung oleh pendapat Yoewana (1990:98-99) mengemukakan "evaluasi sering diartikan sebagai upaya untuk menilai hasil kegiatan. Kaitannya dengan program, evaluasi dapat diartikan sebagai suatu usaha untuk mengukur perkembangan dan keberhasilan suatu program, sejauh mana tujuan yang akan dicapai melalui pelaksanaan program. Evaluasi diperlukan informasi atau data, sehingga evaluasi pada dasarnya merupakan salah satu bagian dari manajemen informasi sistem.

Evaluasi yang dilakukan pada setiap pelatihan, khususnya pelatihan pendamping akreditasi FKTP ini terdiri dari evaluasi pada peserta seperti evaluasi pre test, post test, studi kasus dan komprehensif.
Pertama ada pre test dan post test hampir selalu dilaksanakan pada setiap pelatihan. Khususnya pelatihan pendamping akreditasi FKTP evaluasi pada peserta berbeda dari pelatihan lainnya dengan adanya komprehensif. Komprehensif dilaksanakan bertujuan untuk menilai tingkat pemahaman peserta pelatihan pada keseluruhan materi yang sudah diberikan oleh fasilitator. Kemudian yang kedua adalah evaluasi fasilitator atau narasumber, dan ketiga adalah evaluasi penyelenggaraan pelatihan.

Adanya evaluasi penyelenggaraan pelatihan dikarenakan berfungsi untuk menghimpun saran dan pendapat peserta pelatihan sebagai upaya perbaikan pelatihan yang dilaksanakan selanjutnya. Pendapat senada dikemukakan oleh Kirckpatrick (dalam Widoyoko, 2009:174-178) mengenai jenis evaluasi tingkat Reaction, pendapatnya bahwa, "evaluasi terhadap reaksi untuk mengukur kepuasan peserta pelatihan (customer satisfaction). Program pelatihan dianggap efektif apabila proses pelatihan dirancang menyenangkan dan memuaskan bagi peserta pelatihan, sehingga peserta pelatihan tertarik dan termotivasi untuk belajar dan berlatih. Kepuasan peserta pelatihan dapat dikaji dari beberapa aspek, yaitu materi yang diberikan, fasilitas yang tersedia, strategi penyampaian materi yang digunakan maupun penyajian konsumsi yang disediakan. Tujuan evaluasi program pelatihan adalah untuk menggali informasi mengenai penyelenggaraan pelatihan. Kuisioner penilaian sebagai pedoman untuk mengukur reaksi diharapkan mampu mengungkapkan informasi sebanyak mungkin".

Tujuan lain adanya evaluasi penyelenggaraan adalah untuk perbaikan pelayanan pelatihan, serta digunakan sebagai laporan pertanggungjawaban pelaksanaan pelatihan dapat pula digunakan untuk modifikasi program pelatihan disesuaikan dengan kebutuhan pelatihan.

Hal ini didukung dengan pendapat Arifin (2013:14) yaitu proses evaluasi bertujuan menidentifikasi strategi pembelajaran, meningkatkan efektivitas program, dan menyediakan data yang membantu dalam membuat keputusan. Sasaran evaluasi penyelenggaraan yaitu peserta pelatihan namun yang terlibat dalam evaluasi adalah semua komponen pelaksanaan pelatihan. Pendapat lain dari Wiyono dan Sunarni (2009:9) berpendapat, bila ditinjau dari objek sasarannya 
proses evaluasi program dibedakan atas beberapa jenis, antara lain komponen manajemen pembelajaran, yakni pada tahap perencanaan atau desain pembelajaran, proses pembelajaran dan evaluasi pembelajaran.

Sistematika evaluasi penyelenggaraan disesuaikan dengan pedoman penyelenggaraan pelatihan untuk mempermudah pengambil keputusan (evaluator) dalam melakukan peloparan pelaksanaan pelatihan. Pada tahun 1990 an unsur-unsur evaluasi penyelenggaraan yang dilaksanakan memilik perbedaan pada setiap pelaksanaannya. Proses pelaporan yang dilaksanakan berfungsi untuk memberikan informasi dengan mudah mengenai pelaksanan pelatihan. Adanya perbedaan tersebut dibuatlah pedoman penyelenggaraan pelatihan oleh Kementerian Kesehatan RI pada tahun 2011 sebagai acuhan atau pedoman untuk penyelenggaraan dan evaluasi. Hal tersebut diperkuat dengan pendapat dari Wiyono dan Sunarmi (2009:15) yaitu, "tahaptahap pelaksanaan evaluasi merupakan langkah merealisasi perencanaan program yang telah disusun. Langkah ini mencakup pelaksanaan pengumpulan data dan persifikasi data".

Bedasarkan pernyataan tersebut, evaluasi penyelenggaraan memiliki banyak pengaruh untuk perbaikan program pelatihan yang berikutnya. Sedangkan untuk peserta pelatihan evaluasi penyelenggaraan memiliki pengaruh terhadap pelayanan panitia penyelenggaraan tehadap kebutuhan peserta pelatihan, serta saran dan pendapat yang sudah dihimpun panitia dapat digunakan untuk perbaikan pelatihan yang akan diselenggarakan berikutnya serta dapat digunakan untuk meningkatkan kepercayaan peserta pelatihan terhadap lembaga.

Evaluasi penyelenggaraan yang dilaksanakan oleh lembaga memiliki manfaat untuk mendapatkan informasi tentang berhasil atau tidaknya suatu bentuk pelayanan pelatihan seperti kesiapan penyelenggaraan, proses pembelajaran yang dilakukan oleh fasilitator atau narasumber, dan penunjang pelatihan lainnya, digunakan untuk perbaikan program pelatihan, pengembangan atau modifikasi program pelatihan.

Hal tersebut didukung oleh pendapat Supriyono (2013:17-20), yaitu, untuk (1) mengkomunikasikan program kepada masyarakat luas, (2) memberikan informasi bagi pembuat keputusan, dan (3) menyempurnakan program yang ada serta, (4) meningkatkan partisipasi dan pertumbuhan.

Sesuai dengan pendapat tokoh tersebut evaluasi penyelenggaraan merupakan bentuk laporan dari lembaga untuk memberikan informasi pelaksanaan pelatihan. Prosesntase dipilih pihak lembaga pada proses perhitungannya untuk mempermudah membaca keberhasilan pelaksanaan program.

Berdasarkan unsur-unsur evaluasi penyelenggaraan di UPT Latkesmas Murnajati Lawang terdapat sebelas unsur yang di evaluasi pada penyelenggaraan pelatihan yaitu: (1) pelayanan belajar dalam pelatihan; (2) penggunaan metode pembelajaran oleh fasilitator/narasumber; (3) tingkat semangat belajar (motivasi) mengikuti program pelatihan; (4) tingkat kepuasan peserta pelatihan terhadap penyelenggaraan proses belajar; (5) kenyamanan ruang belajar; (6) penyediaan alat bantu pelatihan; (7) penyediaan pelayanan bahan belajar; (8) kebersihan kamar kecil; (9) pelayanan sekretariat; (10) pelayanan akomodasi; (11) pelayanan konsumsi. Hal tersebut didukung pendapat dari Sudjana (2006:86), menyatakan unsur-unsur yang di evaluasi pada proses penyelenggaraan yaitu: Unsur-unsur program yang temasuk kedalam komponen, proses atau tujuan program. Sumber-sumber program mencakup sumber daya manusia, sumber daya alam dan lingkungan, kebijakan dan peraturan, serta kerjasama antar lembaga penyelenggara program. Perolehan program meliputi keluaran yaitu perubahan perilaku peserta didik atau lulusan, pembelajaran orang lain, dan partisipasi lulusan dalam pembangunan masyarakat.

Adanya penetapan unsur dapat digunakan sebagai acuhan untuk menilai keberhasilan pelaksanaan pelatihan disesuaikan dengan kebutuhan pelatihan dan pengembangan ilmu.

Fungsi dari masing-masing unsur evaluasi penyelenggaraan. Beberapa unsur-unsurnya tersebut memiliki fungsinya masing-masing yaitu: (1) pelayanan belajar dalam pelatihan. Berfungsi menilai proses pembelajaran untuk panitia pelaksana; (2) penggunaan metode pembelajaran oleh fasilitator/narasumber. Berfungsi menilai proses pembelajaran atau gaya mengajar; (3) tingkat semangat belajar (motivasi) mengikuti program pelatihan. Berfungsi menilai pemberian 
motivasi oleh fasilitator; (4) tingkat kepuasan peserta pelatihan terhadap penyelenggaraan proses belajar. Berfungsi untuk menilai penyelenggaraan belajar; (5) kenyamanan ruang belajar. Berfungsi menilai sarana pelatihan; (6) penyediaan alat bantu pelatihan. Berfungsi menilai prasarana pelatihan; (7) penyediaan pelayanan bahan belajar. Berfungsi menilai kesediaan bahan belajar; (8) kebersihan kamar kecil. Berfungsi menilai sarana pelatihan; (9) pelayanan sekretariat. Berfungsi menilai administrasi pelatihan; (10) pelayanan akomodasi. Berfungsi untuk menilai kesiapan pelaksana pelatihan pada akomodasi peserta pelatihan yang melakukan Praktik Kerja Lapangan (PKL) ke tempat diluar lembaga pelatihan; (11) pelayanan konsumsi. Berfungsi untuk menilai ketersediaan konsumsi meliputi coffe break atau konsumsi yang lainnya.

Adanya penetapan unsur-unsur yang dievaluasi menurut hasil wawancara dan observasi tidak menutup kemungkinan penetapan sebelas unsur pada evaluasi penyelenggaraan pelatihan dapat ditambah disesuaikan dengan kebutuhan pelatihan.

Media evaluasi penyelenggaraan media yang digunakan pada evaluasi penyelenggaraan berupa media cetak menggunakan kuisionerpenilaian untuk evaluasi penyelenggaraan dan fasilitator, serta studi kasus atau soal untuk evaluasi peserta. Media kuisioner dipilih sebagai alat untuk mengetahui keberhasilan pelaksanaan pelatihan dikarenakan merupakan satu-satunya media yang mudah untuk dianalisis oleh evaluator lembaga. Kuisioner digunakan untuk membantu memberikan kemudahan peserta pelatihan dalam memberikan penilaian terhadap pelaksanaan pelatihan yang sedang berlangsung.

Hal tersebut didukung oleh pendapat dari Arikunto (2012:40) yaitukuisioner juga sering dikenal sebagai angket. Pada dasarnya adalah sebuah daftar pertanyaan yang harus diisi oleh orang yang dapat diukur (responden). Dengan kuisioner ini penilaian peserta pelatihan dapat diketahui mengenai keadaan atau data diri, pengalaman, pengetahuan sikap, pendapatnya, dan lain-lain. Dengan demikian evaluasi penyelenggaraan difokuskan kepada seluruh kegiatan selama pelatihan mulai dari pembukaan, Praktek Kerja Lapangan (PKL), penutupan serta evaluasi penyelenggaraan pelatihan.

\section{KESIMPULAN DAN SARAN}

\section{Kesimpulan}

Evaluasi penyelenggaraan juga digunakan sebagai acuan dalam pengambilan keputusan dan memperbaiki pelayanan pelatihan. Selain itu alasan UPT Latkesmas Murnajati Lawang melaksanakan evaluasi penyelenggaraan sebagai upaya berkewajiban untuk melaporkan pelaksanaan kegiatan pelatihan dalam bentuk laporan. Laporan penyelenggaraan pelatihan tersebut harus dibuat selambat-lambatnya satu minggu setelah pelatihan berakhir. Diajukan kepada pemilik dana baik pelatihan kerjasama maupun Kementerian Kesehatan Republik Indonesia.

Secara garis besar jenis-jenis evaluasi yang dilaksanakan UPT Latkesmas Murnajati Lawang terbagi menjadi tiga yaitu evaluasi peserta, evaluasi fasilitator, dan evaluasi penyelenggaraan program pelatihan. Evaluasi peserta terdiri dari komponen soal, dan studi kasus, sedangkan evaluasi untuk fasilitator terdiri atas komponen penilaian proses pembelajaran. Evaluasi penyelenggaraan program terdiri dari komponen proses penyelenggaraan, pelayanan, sarana dan prasarana pelatihan dan segala hal pendukung pelatihan yang ingin diketahui unsur-unsur nilainya selama pelaksanaan. Tujuan dilaksanakannya evaluasi penyelenggaraan adalah untuk mendapatkan informasi dari peserta pelatihan tentang berhasil atau tidaknnya pelatihan.

\section{Saran}

Berdasarkan hasil penelitian dapat disimpulkan bahwa evaluasi penyelenggaraan pelatihan pendamping akreditasi fasilitas tingkat pertama dilaksanakan dengan cukup baik oleh UPT Latkesmas Murnajati Lawang. Hasil tersebut akan lebih baik lagi bila terus ditingkatkan. Selain itu, juga dapat menjadi contoh bagi lembaga lainnya untuk melaksanakan evaluasi penyelenggaraan program pelatihan dalam rangka mencapai hasil yang lebih baik.

\section{DAFTAR RUJUKAN}

Komariah \& Satori. 2013. Metodologi Penelitian Kualitatif. Bandung: CV. Alfabeta.

Saleh, M. 2012. Pendidikan Non Formal Bukan Residu. Malang: Fakultas Ilmu Pendidikan Universitas Negeri Malang. 
Patilima, H. 2013. Metode Penelitian Kualitatif. Bandung: Alfabeta.

Sarosa, S. 2012. Penelitian Kualitatif;Dasar-Dasar Penelitian Kualitatif. Jakarta: PT. Indeks.

Ulfatin, N. 2013. Metode Penelitian Kualitatif di Bidang Pendidikan: Teori dan Aplikasinya. Malang: Universitas Negeri Malang

Widoyoko, E. P. 2009. Evaluasi Program Pembelajaran: Panduan Praktik Bagi
Pendidik dan Calon Pendidik. Yogyakarta: Pustaka Pelajar

Wiyono, B. B. \& Sunarni. 2009. Evaluasi Program Pendidikan dan Pembelajran. Malang: Universitas Negeri Malang.

Yoewana, A. 1990, Pengembangan Masyarakat Untuk Para Manajer, Solo: Yayasan Indonesia Sejahtera. 